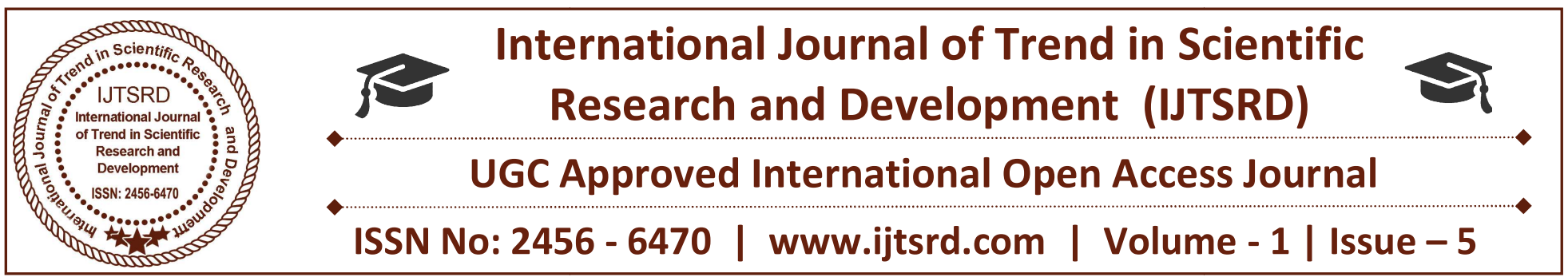

\title{
Evaluation of Interpersonal Relations in University Students
}

López Lazcano Sara B.

Universidad Insurgentes, México
Medina Molina Yearim

Instituto Tecnológico de Milpa

Alta, México

\author{
Rodríguez Cuellar Ruth \\ Instituto Tecnológico de Milpa \\ Alta, México
}

\begin{abstract}
The objective of the present study is to evaluate interpersonal relationships in university students. To carry out this research, a population study was applied and a representative sample was calculated using a $95 \%$ confidence level and a 5\% error allowed. The instrument suggested by Cisneros ( $/ \mathrm{f}$ ) was used to achieve the stated objective. When carrying out this study, we found that 50 students scored 7, 30 students scored 8 , and only 20 students rated 9.
\end{abstract}

Keywords-- Interpersonal relations, evaluation and university students

\section{INTRODUCTION}

Scientific research is a free and creative process. However, this does not mean that it lacks systematicity and organization. Much less if it is the planning stage, which is specified in the research project (Arias, 1999). This is why the present project deals with the interpersonal relationships of engineering students. Taking as pilot test the population of the evening and night shift.

Maceo ( $\mathrm{s} / \mathrm{f}$ ) mentions that communication between people is the fundamental fact that characterizes human relations. Coexistence occurs mainly through interpersonal and social communication. The development of personality and quality of life are largely the result of the effectiveness and quality of interpersonal relationships that are established. From this, the development of man and society has been continuous. However, this does not happen uniformly for all men in the world, nor for all the societies in which they operate.
The present work is inserted between the investigations that enter into the educational work and the relationships that are established in the school group as well as the degree of empathy that will be presented once the students become professionals with a capacity to satisfy the Needs of the current Mexican population. In this context, it is considered that improving interpersonal relationships is fundamental for success at different levels of life; Work, academic, friendship, couple. And it is important to understand that, although we all want, and even need, moments of solitude and reflection, no less certain is that interdependence is key in life (Castiglione, 2016).

For its part, the University of Granada (s / f) mentions that interpersonal relationships comprise all the variety of abilities that a student must acquire in order to be able to participate in an efficient and constructive way in social life, as well as to be able to resolve conflicts When necessary.

The work of the tutor is necessary to promote from the diagnosis the process of individual orientation and positive communication in the collective of students. The fulfillment of their tasks should facilitate the coherence of the educational influences on the members of the group so that it can become a nexus, which solves the dichotomy that is externally appreciated between the work of the classroom, with emphasis on the instructive and the task essentially Of the teacher for the educational work with the students (Maceo, s / f). Investigations carried out by these same authors on this problem have shown that the fundamental cause of indiscipline of some of these 
students in the school is not having found the place to which they aspire within their group, reason why they adopt negative behaviors like strategies To "be taken into account" by their peers and teachers (Pérez Martín, LM 2004, p.219).

Banerjee written by Ashoka (2014) points out that a study by the Workforce Solutions Group, St. Louis Community College, states that more than $60 \%$ of contracting firms claim there is a lack of "communicative and interpersonal skills" Candidates. According to Martha White in his article "The Real Reason College Grads Cannot Get Hired", a high percentage of managers from different companies say that today's candidates In day are not able to think critically or creatively, solve problems or write correctly.

\section{GENERAL OBJECTIVE}

To evaluate the interpersonal relations in university students of industrial engineering in their nocturnal shift.

\section{SPECIFIC OBJECTIVES}

Know the conceptualization of interpersonal relationships.

$>$ Develop an investigation of interpersonal relationships.

Apply the surveys to students of industrial engineering using a $95 \%$ reliability.

Analyze the results of the instrument applied to students of industrial engineering using a 95\% reliability.

$>$ Evaluate the results of the analysis to students of industrial engineering using a $95 \%$ reliability.

\section{CALCULATION OF THE SAMPLE}

A search of the student population that conformed to the industrial engineering was developed. It was found that 134 students make up such engineering. Table 1 shows the distribution of the study population.

\section{Tabla 1: Ejemplo de población de estudio}

\begin{tabular}{|c|c|}
\hline Gender & Total \\
\hline Male & 65 \\
\hline Female & 69 \\
\hline
\end{tabular}

Once the study population was known, the representative sample of the study was calculated. A $95 \%$ confidence interval and a maximum permissible error of $5 \%$ were used for the investigation. The formula used was the one proposed by Dr. Bolaños (2012), which is used for finite or known populations.

The formula is as follows:

$$
n=\left[\frac{Z_{\alpha}^{2} N^{*} p^{*} q}{i^{2}(N-1)+Z_{\alpha}^{2} * p^{*} q}\right]
$$

Where:

$\mathrm{N}$ : sample size

$\mathrm{N}$ : population size

$\mathrm{Z}$ : value corresponding to the gauss distribution, for the investigation $Z=95 \%$, which is equal to 1.96 .

P: expected prevalence of the parameter to be evaluated, if not known $(\mathrm{p}=0.5)$, which makes the sample size larger.

Q: 1 - $\mathrm{p}($ if $\mathrm{p}=70 \%, \mathrm{q}=30 \%$ )

I: error expected to be committed if it is $5 \%, \mathrm{i}=0.05$

The development of the formula is as follows:

$$
n=\left[\frac{(1.96)^{2} * 134 * 0.5 * 0.5}{(0.05)^{2}(134-1)+(1.96)_{6}^{2} * 0.5 * 0.5}\right]=\frac{128.6936}{0.3325+0.9604}=\frac{128.6936}{1.2929}=99.53 \approx 100
$$

The study showed that of a population of 101 students with which industrial engineering counts, using 95\% reliability and 5\% error allowed, will require 114 students for research.

\section{INSTRUMENT USED}

This measurement is carried out on the basis of a protocol system in psychology, the questionnaire was used by Cisneros ( $\mathrm{s} / \mathrm{f}$ ) consisting of 14 reagents, which will measure the level of self-control and 13 
reagents responsible for measuring the level of divided by the total number of reagents in this section empathy Of these students.

\section{METHOD OF EVALUATION OF THE INSTRUMENT}

The evaluation process for young university students will be given in two sections.

\section{Part 1: Self-control}

A rule of three is applied in which the number of negatively charged reagents multiplied by one hundred and divided by the total number of reagents in this section (14) is placed.

\section{Part 2: empathy}

A rule of three is applied in which the reagent number is positively answered multiplied by one hundred and
At the end of these operations the result of both sections is extracted to perform the average and thus give the final percentage of interpersonal relationship with the one that counts the subject.

\section{ANALYSIS OF RESULTS}

Once the theoretical analysis was carried out and the surveys were applied to the representative sample to industrial engineering students, figure 1 shows that 50 students obtained a grade of 7, 30 students had a grade of 8 and only 20 students had a grade of 9

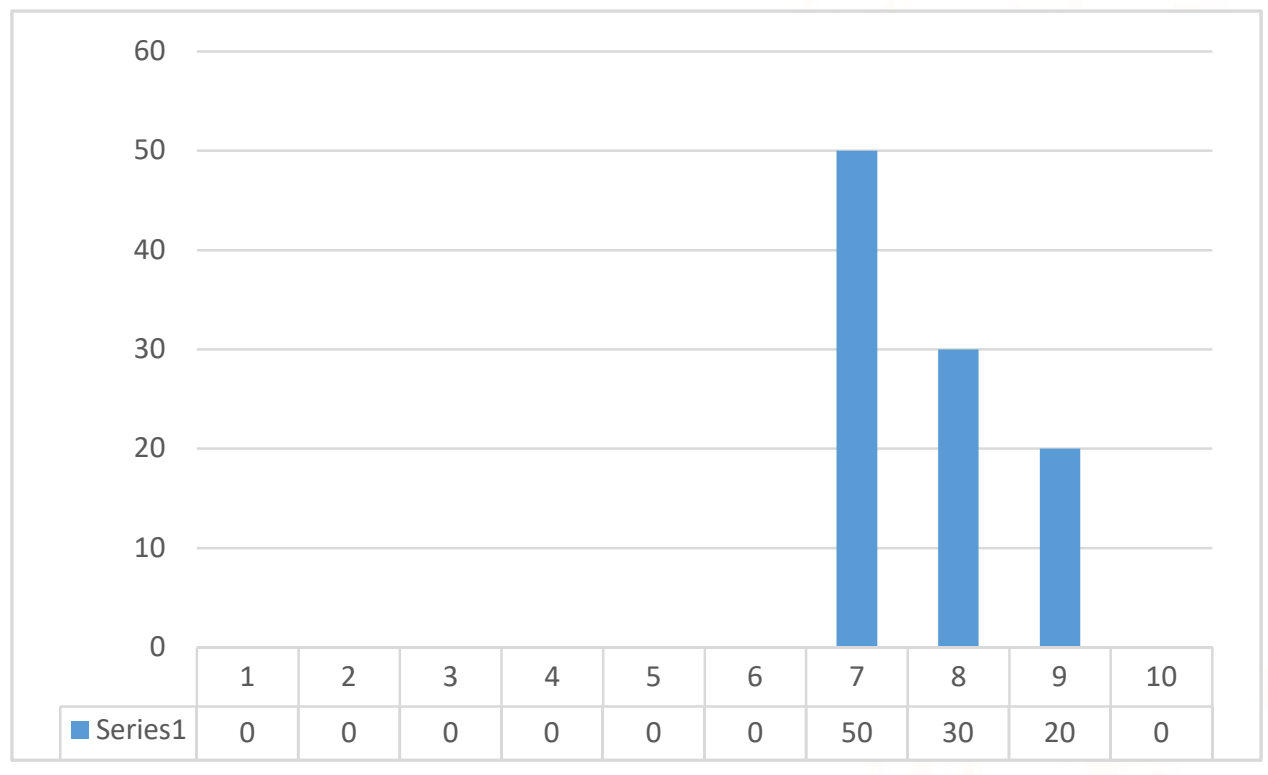

Figure 1: Sample survey results

\section{CONCLUSION}

Based on the research work done by the students of industrial engineering and the statistics released through the test used, it is concluded that the knowledge in real numbers of the percentage of interpersonal relations, which presents in specific the group of night shift students, is good. It expresses that the students are able to have a good management in their interpersonal relationships, demonstrating a good level of self-control and empathy for their peers as well as skills necessary and required to be in a future that demands more and better engineers.

\section{ACKNOWLEDGMENT}

M.I.I. Arturo González Torres for his advice, mentoring and project management.

\section{BIBLIOGRAPHY}

1) Arias, F. G. (1999). El proyecto de investigación. Guía para su elaboración. Editorial Episteme. Orial Ediciones.

2) Ashoka. (2014). La verdadera razón por la que no se contrata a universitarios. Forbes México.

3) Bolaños Rodríguez, E. (2012). Muestra y Muestreo. Asignatura: Estadística para el Desarrollo Tecnológico. Área Académica: Gestión 
Tecnológica. Escuela Superior e Tizayuca. Universidad Autónoma de Hidalgo.

4) Castiglione, L. (2016). Las relaciones interpersonales, ¿claves para el éxito? Inspirulina.

5) Cisneros Castillo, M. (s/f). Test de relaciones interpersonales. Scribd.

6) Maceo Jaque, L. (s/f). Orientación de las relaciones interpersonales en los estudiantes de la educación superior. Monografías.
7) Pérez González, C. C y Colaboradores. (2007). El estudio de la organización higiénica del proceso docente - educativo en las condiciones actuales de la escuela cubana. La Habana: Pueblo y Educación.

8) Universidad de Granada. (s/f). Seminario taller sobre planificación y diseño de la docencia en educación superior desde los planteamientos de formación por competencias. Universidad de Granada.

\section{EJEMPLO DE PRUEBA DE RELACIONES INTERPERSONALES}

Nombre:

\section{INSTRUCCIONES:}

Solicito tu colaboración en dar respuestas al siguiente test. Lee cuidadosamente cada una de las afirmaciones siguientes y decide cuál de ellas te describe correctamente como eres la mayoría de las veces. No existen respuestas correctas o erradas. Marca dentro del recuadro SI (si la afirmación te describe cómo eres la mayoría de las veces). Si piensas que la afirmación no corresponde la mayoría de las veces, marca NO

\section{PARTE 1: AUTOCONTROL}

1.Rara vez pierdo la paciencia

2.Frecuentemente busco hacer otra cosa hay persona que me aburrendemasiado

3.A veces dejo para mañana una tarea sabiendo que debe hacerlo hoy

4.Aunque no es correcto de pagar con la misma moneda a un miembro de mi familia queme trata injustamente, frecuentemente lo hago

5.Si un amigo no cumple con algo que me prometió, lo comprendería en vez de enojarme

6.En ocasiones descargo mi cólera con mis amigos, cuando tengo algún problema

7.Como escondo mis verdaderos sentimientos, la mayoría de laspersonas no se dan cuenta cuando me han herido

8.Me aseguro de que la gente sepa cuál es mi posición con respecto algún punto

9.Hay ocasiones en que no soy completamente honesto (a) con la gente acerca de mis verdaderos sentimientos

10.A veces golpeo a mis compañeros(as) durante una discusión

11.Cuando juego un deporte en equipo, siento que está bien descargar mi cólera físicamente con mis compañeros de juego

12.Antes de contestar de "mala manera" pediría a mis compañeros que esperaran hasta que termine la conversación

13.No sé qué decir cuando alguien me dice algo agradable

14.En algunas ocasiones he golpeado a mi compañero(a) de clase

PARTE II: EMPATÍA

15.Me gusta hacer reconciliar a mis amigos

16.Evito que mis disgustos me alejen de mis amigos

17.Acepto sin molestarme las bromas de mis compañeros 
International Journal of Trend in Scientific Research and Development (IJTSRD) ISSN: 2456-6470

\begin{tabular}{|l|l|}
\hline 18.Acepto los elogios que me dicen mis compañeros & \\
\hline 19.Me gusta hacer bromas a mis compañeros & \\
\hline 20.Defiendo a un amigo cuando lo critican injustamente o lo insultan & \\
\hline 21.Creo que las personas no se deben dejar llevar de rumores & \\
\hline 22. Generalmente expreso afecto a mis compañeros con palabras, gestos o brazos & \\
\hline 23.Evito usar apodos o sobrenombres que insulten o molesten a mis amigos & \\
\hline 24.Pido disculpas cuando cometo un error & \\
\hline 25.Me gusta tener un buen ambiente de amistad entre mis compañeros de trabajo & \\
\hline 26.Escucho con atención cuando un amigo habla u opina en el grupo de trabajo & \\
\hline 27.Escucho atentamente cuando un amigo me conversa o me cuenta un problema & \\
\hline
\end{tabular}

